\title{
LETTER
}

\section{Secondary phosphates in montebrasite and amblygonite from Nagatare, Fukuoka Prefecture, Japan}

\author{
Yohei SHIROSE and Seiichiro UEHARA \\ Department of Earth and Planetary Sciences, Faculty of Sciences, Kyushu University, Fukuoka 812-8581, Japan
}

\begin{abstract}
Montebrasite and amblygonite in an Li-Cs-Ta enriched (LCT) pegmatite from Nagatare, Fukuoka Prefecture, Japan, contain various alteration minerals: fluorapatite, crandallite, goyazite, waylandite, wardite, viitaniemiite, morinite, muscovite, lepidolite, and cookeite. They are associated with lacroixite, quartz, and topaz. Among these minerals, wardite, viitaniemiite, morinite, and lacroixite are newly discovered in Japan. The secondary phosphates and fine-grained mica form fine veins along cleavages and composition planes of polysynthetic twins in the montebrasite and amblygonite. Lacroixite has a different texture from other phosphates, which suggests a possibility of exsolution within montebrasite-amblygonite series. Various secondary phosphates show $\mathrm{Ca}^{-}, \mathrm{Na}^{-}$and $\mathrm{Sr}$-metasomatism with leaching of $\mathrm{Li}$, and the formation of low-F montebrasite from montebrasite-amblygonite series indicates an $\mathrm{F}-\mathrm{OH}$ exchange. However, fluorapatite, morinite, and viitaniemiite crystallized in an F-rich environment. Montebrasite-amblygonite series minerals undergo an acidic alteration to muscovite in the last stage, which is the same process that other Li minerals undergo, such as tourmaline and spodumene.
\end{abstract}

Keywords: Montebrasite-amblygonite series, Viitaniemiite, Morinite, Wardite, Lacroixite

\section{INTRODUCTION}

Minerals of the montebrasite-amblygonite series have complete solid solution with $\mathrm{LiAlPO}_{4}(\mathrm{OH})$ and $\mathrm{LiAl}$ $\mathrm{PO}_{4} \mathrm{~F}$. Minerals of this series generally occur as primary phosphates from Li-Cs-Ta enriched (LCT) (Černý and Ercit, 2005) pegmatites and topaz-bearing granites. Hydrothermal alteration of the montebrasite-amblygonite series to secondary phosphates during the late stages of pegmatite formation has been recorded at several locations (e.g., London and Burt, 1982; Baldwin et al., 2000; Galliski et al., 2012). In Japan, montebrasite-amblygonite series minerals were first described from an LCT pegmatite in Nagatare, Fukuoka Prefecture. Descriptions were based on optical properties observed by Shibata (1934), and chemical composition and X-ray diffraction data of montebrasite were reported by Ito et al. (1955). The occurrence of montebrasite and alteration to muscovite were also reported at Myokenzan, Ibaraki Prefecture (Sakurai et al., 1977). We have been reinvestigating the minerals of the Nagatare pegmatite including lep-

doi:10.2465/jmps.131022d

Y. Shirose, shirose@kyudai.jp Corresponding author

S. Uehara, uehara@geo.kyushu-u.ac.jp idolite (Kataoka and Uehara, 2000), tourmaline (Shirose and Uehara, 2013), and other rare minerals, for example, Bi minerals (Uehara and Shirose, 2013). In this study, montebrasite and amblygonite from the Nagatare pegmatite occur with various alteration minerals: muscovite, lepidolite, cookeite, and secondary phosphates such as fluorapatite, crandallite, goyazite, waylandite, wardite $\left[\mathrm{NaAl}_{3}\left(\mathrm{PO}_{4}\right)_{2}(\mathrm{OH})_{4} \cdot 2 \mathrm{H}_{2} \mathrm{O}\right]$, viitaniemiite $[\mathrm{Na}(\mathrm{Ca}, \mathrm{Mn}) \mathrm{Al}$ $\left.\left(\mathrm{PO}_{4}\right) \mathrm{F}_{2}(\mathrm{OH})\right]$, and morinite $\left[\mathrm{NaCa}_{2} \mathrm{Al}_{2}\left(\mathrm{PO}_{4}\right)_{2} \mathrm{~F}_{4}(\mathrm{OH})\right.$. $\left.2 \mathrm{H}_{2} \mathrm{O}\right]$, associated with lacroixite $\left[\mathrm{NaAl}\left(\mathrm{PO}_{4}\right) \mathrm{F}\right]$, quartz, and topaz. These phosphates generally occur as hydrothermal products in some pegmatites. This is the first discovery of wardite, viitaniemiite, morinite, and lacroixite in Japan, and this paper describes the occurrence and mineralogical properties of these phosphates.

\section{GEOLOGY AND SAMPLE DESCRIPTIONS}

The Nagatare pegmatite is an LCT pegmatite, located at Nagatare, in the western area of Fukuoka City, Fukuoka Prefecture. The pegmatite is derived from the Sawara granite (80-100 Ma) that intruded into the Itoshima granodiorite (70-115 Ma) (Karakida et al., 1994). There are outcrops of barren pegmatite and beryl-containing peg- 
Table 1. Sample numbers with the associated minerals and the properties of montebrasite and amblygonite

\begin{tabular}{|c|c|c|c|c|c|c|c|c|c|c|c|c|c|}
\hline \multirow{2}{*}{$\begin{array}{c}\text { Sample } \\
\text { no. } \\
\end{array}$} & \multirow{2}{*}{$\begin{array}{r}\text { Size } \\
(\mathrm{cm})\end{array}$} & \multirow{2}{*}{ Form } & \multirow{2}{*}{ Color } & \multirow{2}{*}{ Associated minerals* } & \multirow{2}{*}{$\begin{array}{c}\text { F contents** } \\
(\text { apfu) }\end{array}$} & \multicolumn{8}{|c|}{ Phosphates } \\
\hline & & & & & & Ap & $\mathrm{Cdl}$ & Gyz & Vtm & Mor & $\mathrm{Wd}$ & Lcx & $\mathrm{Bi}$ \\
\hline XN162 & 6 & Block & LS-CL-MW & Qtz, Lpd, Ab & 0.59 & 0 & 0 & 0 & & & & 0 & \\
\hline XN165 & 2 & Block & LS-MW & $\mathrm{Ab}, \mathrm{Qtz}$ & 0.56 & O & O & 0 & & & & 0 & 0 \\
\hline XN160 & 4 & Block & CL-MW & (Qtz, Lpd, Ab) & 0.54 & 0 & 0 & 0 & 0 & 0 & 0 & 0 & 0 \\
\hline XN163 & 4 & Block & CL-LS-MW & Qtz & 0.54 & 0 & 0 & O & 0 & 0 & & 0 & \\
\hline XN168 & 0.5 & Dendritic & LS-CL-MW & Kfs, Qtz, Lpd, Ab, (Tur) & 0.50 & O & 0 & O & & & 0 & O & 0 \\
\hline Ng104 & 0.5 & Dendritic & CL-MW & Kfs, Qtz, Lpd, (Ab, Tur) & 0.48 & O & 0 & O & & & O & O & \\
\hline XN167 & 0.3 & Block & CL-MW & Qtz, Lpd, Ab, Kfs, Tur & 0.48 & 0 & O & O & & & & 0 & \\
\hline XN169 & 1 & Block & LS-MW & $\mathrm{Ab},(\mathrm{Qtz}, \mathrm{Lpd})$ & 0.47 & 0 & O & & & & & 0 & \\
\hline Ng107 & 4 & Block & MW & (Qtz, Lpd) & 0.44 & ○ & ○ & & O & & 0 & O & \\
\hline XN164 & 2 & Block & LS-MW & Ab, Ptl, (Lpd) & 0.41 & $\bigcirc$ & O & & & & & 0 & \\
\hline XN166 & 2 & Block & MW & Qtz, Lpd-Ms, (Ab) & 0.40 & 0 & 0 & & & & & 0 & \\
\hline
\end{tabular}

${ }^{*}$ Slightly associated minerals are noted in brackets.

** F contents were estimated from bulk powder XRD patterns for all specimens using Kallio's (1978) method.

LS, light-salmon color; CL, colorless; MW, milky-white color. Qtz, quartz; Lpd, lepidolite; Ab, albite; Kfs, K-feldspar; Tur, Li tourmaline; Ptl, petalite; Ms, muscovite; Ap, fluorapatite; Cdl, crandallite; Gyz, goyazite; Vtm, viitaniemiite; Mor, Morinite; Wd, wardite; Lcx, lacroixite; $\mathrm{Bi}, \mathrm{Bi}$ phosphates.
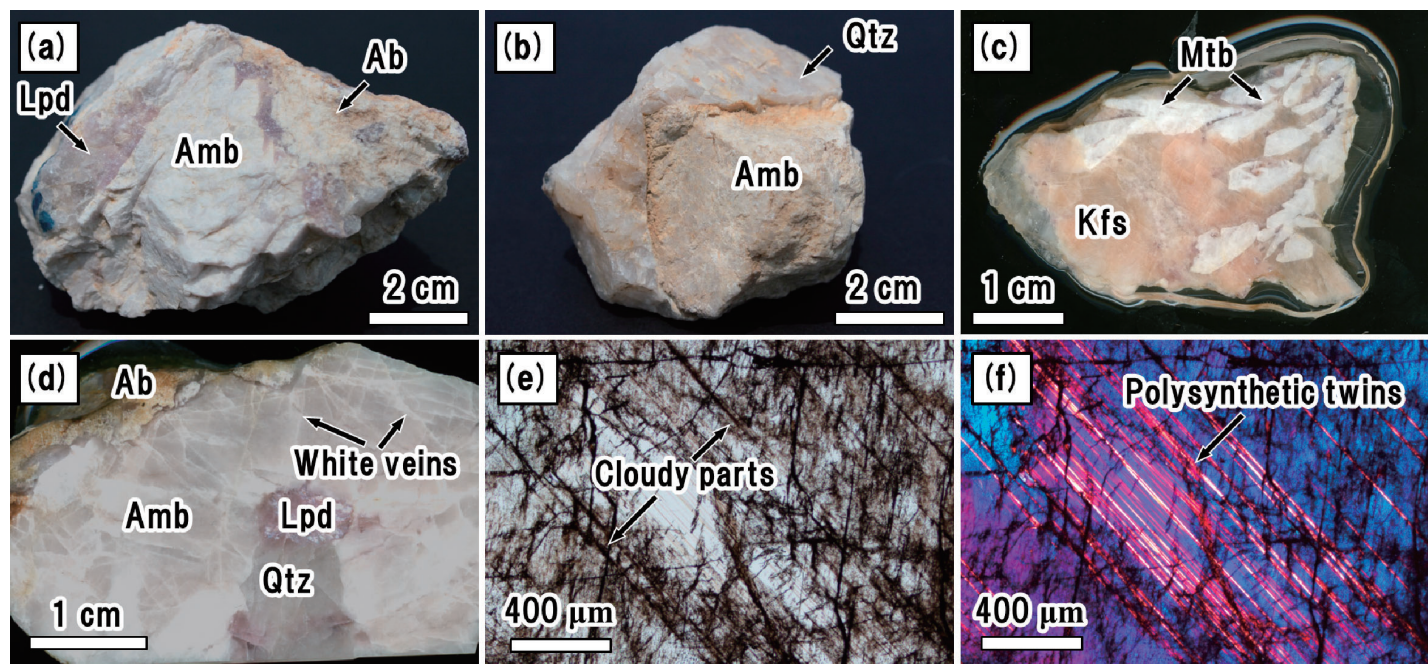

Figure 1. Appearance and optical photomicrograph of montebrasite and amblygonite. (a) and (b) Photographs of subhedral amblygonite from the Nagatare pegmatite (samples XN162 and XN163). (c) Photograph of dendritic montebrasite in K-feldspar from the Nagatare pegmatite (sample Ng104). (d) Cross section of amblygonite (sample XN162). Arrows represent the white veins parallel to the cleavages. (e) and (f) Plane- and cross-polarized optical photomicrographs showing the cloudy parts and the polysynthetic twins of amblygonite (sample XN160). Amb, amblygonite; Mtb, montebrasite; Lpd, lepidolite; Ab, albite; Qtz, quartz; Kfs, K-feldspar.

matite found from the coast to Mt. Nagatare. The Li-enriched pegmatite of Mt. Nagatare was mined for $\mathrm{Li}$ ore in the middle of the 20th century. The ore body contained rare element minerals such as lepidolite, $\mathrm{Li}$ tourmaline, petalite, montebrasite, amblygonite, and pollucite. Eleven specimens used in this study were collected from this old ore deposit (Table 1). The sample numbers are listed with the results of the analyses in Table 1.

The montebrasite and amblygonite from the Nagatare pegmatite occur as large subhedral to euhedral crystals with lepidolite, Li tourmaline and petalite in quartz, and albite (Figs. 1a and 1b). Small dendritic crystals of montebrasite are contained within K-feldspar (Fig. 1c).
The crystals are colorless, milky-white, or light-salmon, and have a vitreous luster. There are white veins parallel to cleavage planes in the cross sections (Fig. 1d). Under the polarizing microscope, montebrasite and amblygonite were mostly cloudy caused by very fine inclusions, and polysynthetic twins were observed (Figs. 1e and 1f). Manganotantalite, microlite, and minor bismuth were also observed as inclusions within montebrasite and amblygonite.

\section{ANALYTICAL METHODS}

Chemical analyses were performed on a JEOL 

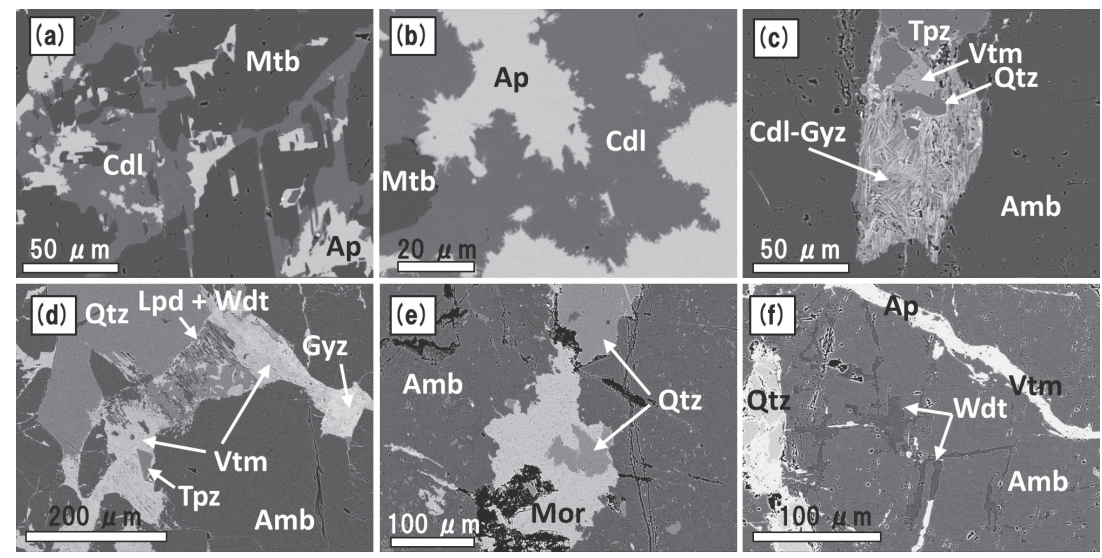

Figure 2. BSE images of the secondary phosphates in the montebrasite and amblygonite. (a) and (b) Crandallite and apatite forming veinlets along cleavages and composition planes of polysynthetic twins in montebrasite (sample $\mathrm{Ng} 107)$. (c) Chemical zoning texture of prismatic crandallitegoyazite series minerals (sample XN160). (d) Viitaniemiite with high fluorine contents silicates (sample XN160). (e) Morinite with quartz (sample XN163). (f) Wardite with veinlets of other phosphates (sample XN160). Mtb, montebrasite; Amb, amblygonite; Cdl, crandallite; Ap, fluorapatite; Gyz, goyazite; Tpz, topaz; Vtm, viitaniemiite; Qtz, quartz; Lpd, lepidolite; Wdt, wardite; Mor, morinite.
JXA8530F electron microprobe (EPMA) equipped with a wavelength dispersive X-ray spectrometer. Quantitative analyses were performed at an accelerating voltage of $15 \mathrm{kV}$, beam current of $2 \mathrm{nA}$, and probe diameter of 5$15 \mu \mathrm{m}$. The standard materials were fluorapatite (for $\mathrm{F} K \alpha$, $\mathrm{P} K \alpha$, and $\mathrm{Ca} K \alpha$ ), albite (for $\mathrm{Na} K \alpha$ ), forsterite (for $\mathrm{Mg} K \alpha$ ), almandine (for $\mathrm{Al} K \alpha$ and $\mathrm{Fe} K \alpha$ ), celestite (for $\mathrm{S} K \alpha$ and $\operatorname{Sr} L \alpha$ ), and rhodonite (for $\mathrm{Mn} K \alpha$ ). Analyses of montebrasite and amblygonite were performed with the other appropriate standard set: fluorphlogopite (for $\mathrm{F} K \alpha$ ), spodumene (for $\mathrm{Al} K \alpha$ ), $\mathrm{KTiOPO}_{4}$ (for $\mathrm{P} K \alpha$ ), albite (for $\mathrm{Na} K \alpha$ ), diopside $(\mathrm{Ca} K \alpha$ ), and almandine (for $\mathrm{Fe} K \alpha$ ). This standard set was chosen to increase accuracy by using standards with similar concentrations to the specimens. The ZAF method was used for data correction. Samples of the crandallite-goyazite series and wardite suffered extensive damage from the electron beam. X-ray diffraction (XRD) data was collected on crystal fragments using a Rigaku RINT RAPIDII curved imaging plate microdiffractometer that used monochromatized $\mathrm{CuK \alpha}$ radiation generated at $40 \mathrm{kV}$ and $30 \mathrm{~mA}$. The fragments were randomized using a Gandolfi-like motion about two axes (oscillation on $\omega$ and rotation on $\varphi$ ). The XRD data of crandallite-goyazite series, viitaniemiite, morinite, and wardite were referenced using PDF cards: \#01-0862315 (Kato, 1971), \#00-035-0598 (Ramik et al., 1983), \#01-076-1881 (Hawthorne, 1979), and \#01-070-2154 (Fanfani et al., 1970), respectively.

\section{DESCRIPTION OF MINERALS}

Macroscopic white veins correspond to the veins of finegrained secondary minerals (Fig. 1d). The thin veins are under $400 \mu \mathrm{m}$ in width, found along cleavages and composition planes of polysynthetic twins in montebrasite and amblygonite, and composed of fine-grained mica and secondary phosphates (Fig. 2). Phosphates were sort- ed into $\mathrm{Ca}$ phosphates, $\mathrm{Na}-\mathrm{Ca}$ phosphates, and $\mathrm{Na}$ phosphates. The chemical compositions and the XRD data are in Table 2 and Appendix tables 1-4, respectively. Fluorine contents for montebrasite-amblygonite series minerals were estimated from bulk powder XRD patterns for all specimens using Kallio's method (1978). The obtained values of $\mathrm{F} /(\mathrm{F}+\mathrm{OH})$ in the bulk compositions are 0.40-0.59 (Table 1). However, EPMA analyses show they are partially replaced by low-F montebrasite (Fig. 3 and Table 3). The detailed mineralogical studies of montebrasite, amblygonite, and lacroixite will be reported in another paper (Shirose and Uehara, in prep.).

\section{Ca phosphates}

Fluorapatite and crandallite are found in all specimens (Table 1). Fluorapatite forms veinlets composed of radial aggregates of acicular crystals (Figs. $2 \mathrm{a}$ and $2 \mathrm{~b}$ ). Grained single crystals of fluorapatite are also included in montebrasite and amblygonite. While some grained fluorapatites contain $\mathrm{Mn}$ and $\mathrm{Sr}$, acicular fluorapatite has relatively poor $\mathrm{Mn}$ content and no $\mathrm{Sr}$ content. Regarding $\mathrm{F}$ content, the fluorapatite grains are mostly fluorapatite end-member, and some hydroxylapatites exist with muscovite. Crandallite occurs in acicular to tabular aggregates as veinlets (Figs. 2a and 2b) and contains $\mathrm{Sr}$ in some specimens (Table 2). Goyazite, the Sr analogue of crandallite, also occurs with crandallite (Fig. 2c and Table 2) and exhibits compositional zoning textures. The unit cell parameters of sample XN162 are close to that of goyazite, reflecting the composition (Appendix table 1). The Nagatare goyazite is the first $\mathrm{Sr}$ mineral found in the pegmatite.

\section{Na-Ca phosphates}

Viitaniemiite and morinite are high-F species compared 
Table 2. Chemical composition of the phosphates in the montebrasite and amblygonite from the Nagatare pegmatite

\begin{tabular}{|c|c|c|c|c|c|c|c|c|c|}
\hline \multirow{2}{*}{$\begin{array}{l}\text { Species } \\
\text { Sample no. } \\
\text { n* }\end{array}$} & \multicolumn{2}{|c|}{ Crandallite } & \multirow{2}{*}{$\begin{array}{c}\text { Goyazite } \\
\text { XN163 } \\
2 \\
\end{array}$} & \multirow{2}{*}{$\begin{array}{c}\text { Fluorapatite } \\
\text { XN164 } \\
3 \\
\end{array}$} & \multicolumn{2}{|c|}{ Viitaniemiite } & \multirow{2}{*}{$\begin{array}{c}\text { Morinite } \\
\text { XN163 } \\
3 \\
\end{array}$} & \multirow{2}{*}{$\begin{array}{c}\text { Wardite } \\
\text { XN160 } \\
4\end{array}$} & \multirow{2}{*}{$\begin{array}{c}\text { Lacroixite } \\
\mathrm{XN163} \\
2 \\
\end{array}$} \\
\hline & $\begin{array}{c}\mathrm{Ng} 107 \\
3 \\
\end{array}$ & $\begin{array}{c}\text { XN166 } \\
1 \\
\end{array}$ & & & $\begin{array}{c}\text { XN163 } \\
3 \\
\end{array}$ & $\begin{array}{c}\mathrm{XN160} \\
5 \\
\end{array}$ & & & \\
\hline $\mathrm{SO}_{3}$ & $0.7 \quad(4)$ & 0.1 & - & $0.0 \quad(0)$ & - & - & - & - & - \\
\hline $\mathrm{P}_{2} \mathrm{O}_{5}$ & 33.2 (1) & 32.3 & $29.2 \quad(7)$ & $43.1 \quad(7)$ & 31.4 (3) & 28.7 (9) & $30.5 \quad(2)$ & 36.2 & $45.5 \quad(2)$ \\
\hline $\mathrm{Al}_{2} \mathrm{O}_{3}$ & $32.6 \quad(3)$ & 30.8 & 30.0 & $0.3 \quad(2)$ & $20.2(5)$ & 20.4 & 19.9 (4) & 34.6 & $29.4(0)$ \\
\hline $\mathrm{MgO}$ & - & - & - & - & 2.2 (13) & 0.2 & - & - & - \\
\hline $\mathrm{CaO}$ & 13.0 & 8.1 & 0.2 & $56.0(6)$ & 20.9 (24) & 21.8 & 23.2 & 0.2 (1) & $0.4 \quad(3)$ \\
\hline $\mathrm{MnO}$ & - & - & - & $0.9 \quad(6)$ & $0.4 \quad(2)$ & 1.2 (4) & - & - & - \\
\hline $\mathrm{SrO}$ & $0.0 \quad(1)$ & 7.0 & 19.2 & $0.0 \quad(0)$ & - & - & - & - & - \\
\hline $\mathrm{Na}_{2} \mathrm{O}$ & $0.0(0)$ & 0.0 & - & $0.0 \quad(0)$ & $12.7(2)$ & 11.8 & $6.2(1)$ & 7.1 (1) & 16.8 \\
\hline $\mathrm{F}$ & 1.9 (3) & 1.0 & $1.6(1)$ & 3.9 (4) & 13.0 & 13.6 & 12.8 & $1.6(7)$ & $10.4 \quad(3)$ \\
\hline $\mathrm{H}_{2} \mathrm{O}^{* *}$ & 13.4 & 13.1 & 11.9 & 0.0 & 5.2 & 4.4 & 10.7 & 16.6 & 0.6 \\
\hline $\mathrm{O}=\mathrm{F}$ & 0.8 & 0.4 & 0.7 & 1.6 & 5.5 & 5.7 & 5.4 & 0.7 & 4.4 \\
\hline \multirow[t]{2}{*}{ Total } & 94.2 & 92.0 & 91.4 & 102.7 & 99.9 & 96.5 & 98.1 & 95.7 & 98.7 \\
\hline & \multicolumn{2}{|c|}{$\mathrm{O}=10.5$} & $\mathrm{O}=10.5$ & $\mathrm{O}=12.5$ & \multicolumn{2}{|c|}{$\mathrm{O}=5.5$} & $\mathrm{O}=10.5$ & $\mathrm{O}=10.0$ & $\mathrm{O}=4.5$ \\
\hline S apfu & $0.04 \quad(2)$ & 0.01 & - & 0.00 & - & - & - & - & - \\
\hline $\mathrm{P}$ & 2.06 & 2.12 & $2.06 \quad(2)$ & $2.99 \quad(2)$ & 1.05 (1) & 1.00 & 2.07 & 2.12 & $1.05(0)$ \\
\hline $\mathrm{Al}$ & 2.81 & 2.81 & 2.94 (4) & $0.03 \quad(2)$ & $0.94 \quad(2)$ & $1.00 \quad(2)$ & 1.88 & 2.81 & $0.95 \quad(1)$ \\
\hline $\mathrm{Mg}$ & - & & - & - & $0.08 \quad(9)$ & $0.01 \quad(9)$ & - & - & - \\
\hline $\mathrm{Ca}$ & $1.02 \quad(2)$ & 0.67 & $0.02 \quad(1)$ & $4.92 \quad(9)$ & 0.89 (11) & $0.97 \quad(11)$ & 2.00 & $0.01 \quad(1)$ & $0.01 \quad(1)$ \\
\hline $\mathrm{Mn}$ & - & & - & $0.06 \quad(4)$ & $0.01 \quad(1)$ & 0.04 (1) & - & - & - \\
\hline $\mathrm{Sr}$ & $0.00(0)$ & 0.32 & $0.93 \quad(0)$ & $0.00 \quad(0)$ & - & - & - & - & - \\
\hline $\mathrm{Na}$ & $0.00 \quad(0)$ & 0.00 & - & $0.00 \quad(0)$ & $0.97 \quad(2)$ & $0.95 \quad(2)$ & $0.97 \quad(2)$ & $0.96 \quad(2)$ & 0.89 \\
\hline $\mathrm{F}$ & $0.44 \quad(8)$ & 0.25 & $0.43 \quad$ (4) & $1.01 \quad(10)$ & $1.63(9)$ & 1.78 (9) & 3.24 (7) & $0.34 \quad(15)$ & $0.90 \quad(2)$ \\
\hline $\mathrm{OH}$ & $4.56 \quad(8)$ & 4.75 & $4.57 \quad(4)$ & 0.00 & 1.37 & 1.22 & 1.76 & 3.66 (15) & $0.10 \quad(2)$ \\
\hline Cation sum & 5.93 & 5.91 & 5.94 & 8.00 & 3.94 & 3.97 & 6.93 & 5.90 & 2.89 \\
\hline
\end{tabular}

* Number of analyzed spots.

${ }^{* *} \mathrm{H}_{2} \mathrm{O}$ contents were calculated by stoichiometry.

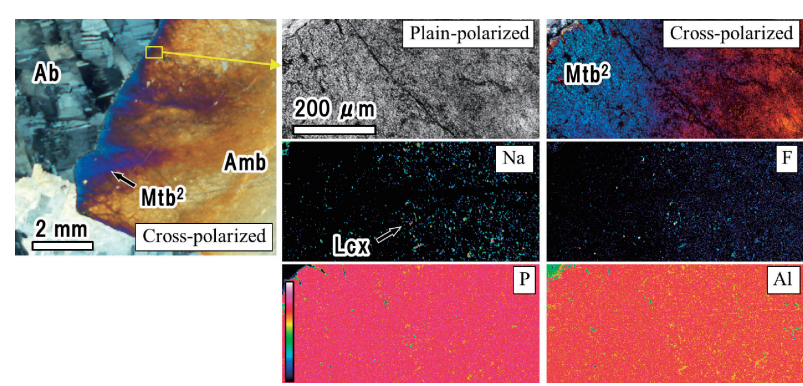

Figure 3. Plane- and cross-polarized optical photomicrograph and $\mathrm{X}$-ray images of elements distribution map ( $\mathrm{Na} K \alpha, \mathrm{F} K \alpha, \mathrm{P} K \alpha$, and $\mathrm{A} 1 K \alpha$ ), indicating the replacement by low-F montebrasite (sample XN165). The part with blue interference-color is secondary montebrasite similar to London and Burt (1982), and it has low $\mathrm{F}$ content. Ab, albite; Amb, amblygonite; $\mathrm{Mtb}^{2}$, secondary low-F montebrasite; Lcx, lacroixite.

to other phosphates, and they are present in a few specimens as veinlets composed of micro-tabular crystals (Figs. 2d and 2e). In this locality, viitaniemiite is usually associated with lepidolite and topaz, and contains Mn and $\mathrm{Mg}$ as minor elements (Table 2). The chemical compositions and unit cell parameters are more similar to $\mathrm{Mn}$-free viitaniemiite (Ramik et al., 1983; Breiter et al., 2009) than Mn-bearing (up to $0.4 \mathrm{apfu}$ ) viitaniemiite (Lathi, 1981; Petrík et al., 2011) (Appendix table 2). The veinlets of morinite include fluorapatite and zoned crystals of the crandallite-goyazite series, extending $2 \mathrm{~cm}$ in length and $20 \mu \mathrm{m}$ in width. Morinite has no $\mathrm{Mn}$ or $\mathrm{Mg}$ and has slightly lower $\mathrm{F}$ than the ideal formula as with the viitaniemiite (Table 2). The unit cell parameters are in good agreement with those of morinite (Hawthorne, 1979) (Appendix table 3).

\section{Na phosphates}

Wardite occurs in veinlets like the other phosphates, but these are cut by or shifted into $\mathrm{Ca}$ phosphate and $\mathrm{Na}-\mathrm{Ca}$ phosphate (Fig. 2f). Wardite from Nagatare has slightly larger unit cell parameters than that from Fairfield (Fanfani et al., 1970; Appendix table 4), and this difference is caused by slightly-contained F (Table 2). Lacroixite is found in all specimens as scattered lamella embedded in montebrasite and amblygonite, unlike other secondary phosphates (Figs. 3 and 4). This texture is similar to "natromontebrasite', a discredited species that was deter- 
Table 3. Representative chemical composition of the amblygonite, montebrasite, and low-F montebrasite from the Nagatare pegmatite

\begin{tabular}{|c|c|c|c|}
\hline Species & Amblygonite & Montebrasite & $\begin{array}{c}\text { Low-F } \\
\text { montebrasite }\end{array}$ \\
\hline Sample no. & XN160 & XN166 & XN165 \\
\hline $\mathrm{P}_{2} \mathrm{O}_{5}$ & 47.72 & 48.33 & 48.16 \\
\hline $\mathrm{Al}_{2} \mathrm{O}_{3}$ & 34.53 & 34.61 & 35.04 \\
\hline $\mathrm{CaO}$ & 0.00 & 0.02 & 0.03 \\
\hline $\mathrm{FeO}$ & 0.01 & 0.00 & 0.00 \\
\hline $\mathrm{Li}_{2} \mathrm{O}^{*}$ & 10.07 & 10.16 & 10.19 \\
\hline $\mathrm{Na}_{2} \mathrm{O}$ & 0.00 & 0.00 & 0.01 \\
\hline $\mathrm{F}$ & 7.12 & 3.84 & 1.36 \\
\hline $\mathrm{H}_{2} \mathrm{O}^{*}$ & 2.70 & 4.31 & 5.50 \\
\hline $\mathrm{O}=\mathrm{F}$ & 3.00 & 1.62 & 0.57 \\
\hline \multirow[t]{2}{*}{ Total } & 99.15 & 99.64 & 99.71 \\
\hline & & $\mathrm{O}=4.5$ & \\
\hline $\mathrm{P}$ & 1.00 & 1.00 & 0.99 \\
\hline $\mathrm{Al}$ & 1.00 & 1.00 & 1.01 \\
\hline $\mathrm{Ca}$ & 0.00 & 0.00 & 0.00 \\
\hline $\mathrm{Fe}$ & 0.00 & 0.00 & 0.00 \\
\hline $\mathrm{Li}$ & 1.00 & 1.00 & 1.00 \\
\hline $\mathrm{Na}$ & 0.00 & 0.00 & 0.00 \\
\hline $\mathrm{F}$ & 0.56 & 0.30 & 0.10 \\
\hline $\mathrm{OH}$ & 0.44 & 0.70 & 0.90 \\
\hline Cation sum & 3.00 & 3.00 & 3.00 \\
\hline
\end{tabular}

${ }^{*} \mathrm{Li}_{2} \mathrm{O}$ and $\mathrm{H}_{2} \mathrm{O}$ contents were calculated by stoichiometry.

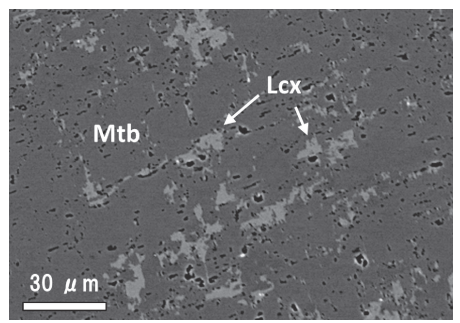

Figure 4. Scattered lamella of lacroixite embedded in montebrasite (sample $\mathrm{Ng} 107$ ). Mtb, montebrasite; Lcx, lacroixite.

mined to be a mixture of an $\mathrm{OH}$-rich amblygonite and lacroixite (Fransolet, 1989; Fransolet et al., 2007). The montebrasite-amblygonite series is topologically identical to the lacroixite structure, and $\mathrm{Na}$ could not substitute $\mathrm{Li}$ at low temperatures in the montebrasite-amblygonite structure (Groat et al., 1990) (Table 3). Thus, it is possible that lacroixite is exsoluted as a Na-bearing phase as the temperature decreased and is subsequently distributed within montebrasite and amblygonite.

\section{DISCUSSION}

Montebrasite and amblygonite from the Nagatare pegmatite underwent staged metasomatic alteration. The formation of low-F montebrasite from montebrasite and amblygonite indicates an $\mathrm{F}-\mathrm{OH}$ exchange, and various secondary phosphates show $\mathrm{Ca}^{-}, \mathrm{Na}^{-}$and $\mathrm{Sr}$-metasomatism,

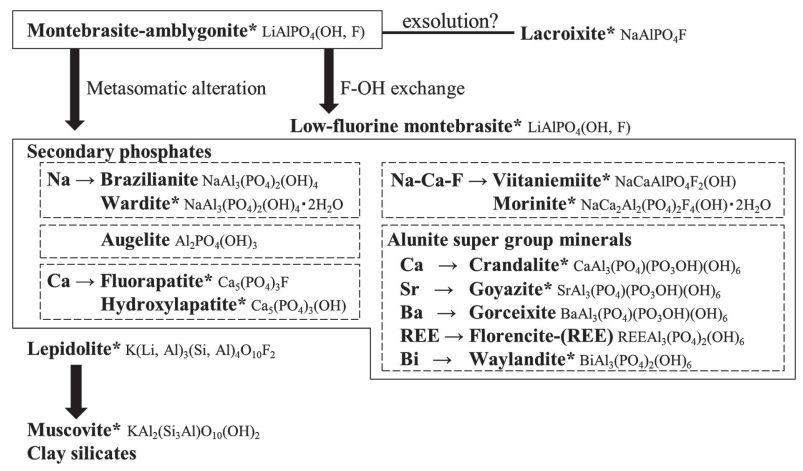

Figure 5. General alteration sequence of montebrasite-amblygonite series without $\mathrm{Fe}$ and $\mathrm{Mn}$ phosphates. Asterisk represents the minerals that occurred in the Nagatare pegmatite.

with leaching of Li. However, the existence of fluorapatite, morinite, and viitaniemiite indicates that they formed in an F-rich environment. The low Mn content of viitaniemiite and the lack of $\mathrm{Fe}$ and $\mathrm{Mn}$ phosphates as replacements of montebrasite and amblygonite indicate that these secondary phosphates crystallized in an $\mathrm{Fe}^{-}$and $\mathrm{Mn}$-free environment differing from the other stages [e.g., triplite occurring stage (Uehara et al., 2010)] in the Nagatare pegmatite.

A sequence of metasomatic alterations of the montebrasite-amblygonite series minerals from the pegmatites of the White Picacho District was established by London and Burt (1982) in the following order: montebrasite $\rightarrow$ low-F montebrasite $\rightarrow$ hydroxylapatite + crandallite $\rightarrow$ hydroxylapatite + muscovite + brazilianite + augelite $+\mathrm{Fe}$ and $\mathrm{Mn}$ phosphates $\rightarrow$ muscovite $\rightarrow$ carbonate-apatite. Similar sequences are reported from other pegmatites (e.g., Baldwin et al., 2000; Galliski et al., 2012) where goyazite and gorceixite are included, and $\mathrm{Fe}$ and Mn phosphates are absent, unlike in the case of the White Picacho District. The Nagatare pegmatite displays characteristic wardite, not brazilianite, morinite, and viitaniemiite formation. Integration of the previous sequences and that of the Nagatare pegmatite results in a general alteration sequence of montebrasite-amblygonite series minerals without $\mathrm{Fe}$ and $\mathrm{Mn}$ phosphates (Fig. 5). Lacroixite has a different texture than other phosphates, and this indicates a possibility of exsolution within the montebrasite-amblygonite series. Crandallite generally occurs as a secondary phosphate in the montebrasite-amblygonite series, and the same group of minerals also occurs depending on the chemical environments, which behaves as a sensitive chemical indicator corresponding to the chemical compositions of the solid solutions. The montebrasite-amblygonite series minerals undergo an acidic alteration to muscovite in the last stage, which is the same process that other Li minerals undergo, 
such as tourmaline (Ahn and Buseck, 1998) and spodumene (London and Burt, 1982).

\section{ACKNOWLEGMENTS}

We are grateful to Dr. S. Matsubara, National Museum of Nature and Science, and an anonymous reviewer for their constructive and critical comments on the manuscript. Associate editor N. Shimobayashi was helpful in improving the manuscript. We appreciate Mr. K. Shimada, Department of Earth and Planetary Sciences, Faculty of Sciences, Kyushu University, for technical support with chemical analyses. The author Y. S. thanks the Professor Matsumoto Scholarship Fund.

\section{SUPPLEMENTARY MATERIALS}

Appendixes tables 1-4 are available online from http:// japanlinkcenter.org/DN/JST.JSTAGE/jmps/131022d.

\section{REFERENCES}

Ahn, J.H. and Buseck, P.R. (1998) Transmission electron microscopy of muscovite alteration of tourmaline. American Mineralogist, 83, 535-541.

Baldwin, J.R., Hill, P.G., von Knorring, O. and Oliver, G.J.H. (2000) Exotic aluminium phosphates, natromontebrasite, brazilianite, goyazite, gorceixite and crandallite from rare-element pegmatites in Namibia. Mineralogical Magazine, 64, $1147-1164$

Breiter, K., Škoda, R. and Veselovský, F. (2009) Unusual P-, Liand Sn-rich pegmatite from Vernéřov near Aš, Czech Republic. Bulletin mineralogicko-petrologického oddělení, 17, 4159 (in Czech with English abstract)

Črný, P. and Ercit, T.S. (2005) The classification of granitic pegmatites revisited. Canadian Mineralogist, 43, 2005-2026.

Fanfani, L., Nunzi, A. and Zanazzi, P.F. (1970) The crystal structure of wardite. Mineralogical Magazine, 37, 598-605.

Fransolet, A.-M. (1989) The problem of Na-Li substitution in primary Li-Al phosphates: new data on lacroixite, a relatively widespread mineral. Canadian Mineralogist, 27, 211-217.

Fransolet, A.-M., Fontan, F. and de Parseval, P. (2007) Natromontebrasite, a discredited mineral species. Canadian Mineralogist, 45, 391-396.

Galliski, M.Á., Cerný, P., Márquez-Zavalía, M.F. and Chapman, R. (2012) An association of secondary Al-Li-Be-Ca-Sr phosphates in the San Elías pegmatite, San Luis, Argentina. Canadian Mineralogist, 50, 933-942.

Groat, L.A., Raudsepp, M., Hawthorne, F.C., Ercit, T.S., Sherriff, B.L. and Hartman, J.S. (1990) The amblygonite-montebrasite series: Characterization by single-crystal structure refinement, infrared spectroscopy, and multinuclear MAS-NMR spectros- copy. American Mineralogist, 75, 992-1008.

Hawthorne, F.C. (1979) The crystal structure of morinite. Canadian Mineralogist, 17, 93-102.

Ito, J., Minato, H. and Okamoto, Y. (1955) On amblygonite from Nagatare-yama, Fukuoka Prefecture. Journal of the Mineralogical Society of Japan, 2, 263-267 (in Japanese).

Kallio, P. (1978) A new X-ray method for the estimation of fluorine content in montebrasites. American Mineralogist, 63, 1249-1251.

Karakida, Y., Tomita, S., Shimoyama, S. and Chijiwa, K. (1994) Geology of the Fukuoka district, Geological Sheet Map 1:50,000, Fukuoka (14) No. 51, pp. 192, Geological Survey of Japan, Tokyo (in Japanese with English abstract).

Kataoka, Y. and Uehara, S. (2000) Lepidolite in a lithium pegmatite from Nagatare, Fukuoka Prefecture, Japan. Abstract of 2000 Annual Meeting of the Mineralogical Society of Japan, 101 (in Japanese)

Kato, T. (1971) The crystal structures of goyazite and woodhouseite. Neues Jahrbuch für Mineralogie, Monatshefte, 1971, 241-247.

Lathi, S.I. (1981) On the granitic pegmatites of the Eräjärvi area in Orivesi, southern Finland. Geological Survey of Finland, pp. 82, Bulletin 314.

London, D. and Burt, D.M. (1982) Alteration of spodumene, montebrasite and lithiophilite in pegmatites of the White Picacho District, Arizona. American Mineralogist, 67, 97-113.

Petrík, I., Kubiš, M., Konečný, P., Broska, I. and Malachovský, P. (2011) Rare phosphates from the Surovec topaz-Li-mica microgranite, Gemeric unit, western Carpathians, Slovak Republic: role of $\mathrm{F} / \mathrm{H}_{2} \mathrm{O}$ of the melt. Canadian Mineralogist, 49, 521-540.

Ramik, R.A., Struman, B.D., Roberts, A.C. and Dunn, P.J. (1983) Viitaniemiite from the Francon quarry, Montreal, Quebec. Canadian Mineralogist, 21, 499-502.

Sakurai, K., Bunno, M., Aoki, M. and Suzuki, Y. (1977) Some minerals in lithium pegmatites from Myokenzan, Ibaraki Prefecture. Journal of Mineralogy, Petrology and Economic Geology, 72, 13-27 (in Japanese with English abstract).

Shibata, H. (1934) Lithium pegmatite from Nagatare, Imajuku Village, Itoshima Country, Fukuoka Prefecture. Journal of the Geological Society of Japan, 41, 582-603 (in Japanese).

Shirose, Y. and Uehara, S. (2013) Li tourmaline from Nagatare, Fukuoka Prefecture, Japan. Journal of Mineralogical and Petrological Sciences, 108, 238-243.

Uehara, S., Mori, Y. and Kawano, H. (2010) Triplite from Nagatare, Fukuoka Prefecture. Abstracts of 2010 Annual Meeting of Japan Association of Mineralogical Sciences, 94 (in Japanese).

Uehara, S. and Shirose, Y. (2013) Namibite and hechtsbergite from the Nagatare mine, Fukuoka Prefecture, Japan. Mineralogical and Petrological Sciences, 108, 105-110.

Manuscript received October 22, 2013

Manuscript accepted March 7, 2014

Manuscript handled by Norimasa Shimobayashi 